ISSN 0258-7122 (Print), 2408-8293 (Online)

Bangladesh J. Agril. Res. 42(4): 631-646, December 2017

\title{
PERFORMANCE OF PRE- AND POST-EMERGENCE HERBICIDES IN STRIP TILLAGE NON-PUDDLED TRANSPLANTED AMAN RICE
}

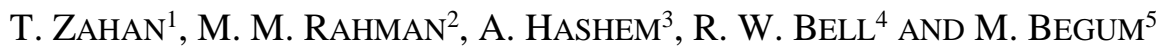

\begin{abstract}
A study was conducted on transplanted aman rice (cv. BINA dhan-7) in striptilled non-puddled field with some commonly used rice herbicides (preemergence: pyrazosulfuron-ethyl and butachlor, early post-emergence: orthosulfamuron and late post-emergence: acetochlor + bensulfuron methyl, butachlor + propanil and 2,4-D amine) applied singly or in sequences during 2013 and 2014 at field laboratory, Bangladesh Agricultural University, Mymensingh to evaluate the effect of those herbicides on weeds as well as growth and yield of aman rice in strip-tilled non-puddled condition. The study showed that herbicides significantly reduced weed density by $75-94 \%$ in 2013 and $46-98 \%$ in 2014 compared to the weedy check. Sole application of pre- or early post-emergence herbicide provided less weed control than sequential application of pre-, early post- and late post-emergence herbicides or application of pre- and late post-emergence herbicides. A wide range of sequential application of herbicide treatments has identified in the study that provided control on weed density and biomass by $49-98 \%$ and $56-95 \%$, respectively. Application of pyrazosulfuron-ethyl followed by orthosulfamuron and butachlor + propanil was the most effective combination in this new rice establishment condition that controlled all types of weeds successfully and provided maximum grain yield (5.42 $\mathrm{t} \mathrm{ha}^{-1}$ in 2013 and $6.18 \mathrm{t} \mathrm{ha}^{-1}$ in 2014) with highest economic return (Tk. 55930 ha $^{-1}$ in 2013 and Tk. 69057 ha $^{-1}$ in 2014). The study suggests economically beneficial some combinations of currently used herbicides for strip-tlled non-puddled transplanted aman rice that may help farmers to choose and rotate in the same land yearwise for obtaining optimum yield.
\end{abstract}

Keywords: Chemical weed control, Herbicide rotation, Non-puddled transplanted rice, Strip tillage, Weed infestation.

\section{Introduction}

Puddling of soil before transplanting rice (Oryza sativa) helps to suppress weeds during crop establishment but this practice is tedious, costly, time and energyconsuming (Gill et al., 2014). Moreover, puddling changes soil physical properties caused detriment to the succeeding non-rice crops in a rotation (Singh et al., 2014 and Kumar et al., 2012). On the other hand, non-puddled transplanting is an emerging option to overcome these problems (Haque et al.,

${ }^{1}$ Scientific Officer, OFRD, Bangladesh Agricultural Research Institute (BARI), Gazipur1701, Bangladesh, ${ }^{2 \& 5}$ Bangladesh Agricultural University (BAU), Mymensingh-2202, Bangladesh, ${ }^{3}$ Department of Agriculture and Food, Western Australia, Australia, ${ }^{4}$ Murdoch University, Perth, Australia 
2016 and Pandey et al., 2012) and also reduce cost of rice cultivation (Islam et al., 2014). Rice established by non-puddled transplanting gives similar or higher yield than that of puddled transplanted rice (Haque et al., 2016; Islam et al., 2014; Ladha et al., 2009), but grain yield may sharply decline if weed management is not done properly (Zahan et al., 2014; Ekeleme et al. 2007).

In conventional puddled transplanting systems, existing weeds are controlled by burying weed seeds into the saturated and submerged soil that results in less early post-emergence of weeds (Swanton et al., 2000; Chauhan et al., 2006). By contrast, pre-planting non-selective herbicides must be used to kill the existing weeds on the non-puddled field to achieve a similar low weed competition at crop establishment (Hartzler and Owen, 1997; Nalewaja, 2003). Depending on the density and type of weeds after rice transplantation, different effective herbicides need to be applied in this reduced tilled field because crop has to compete with huge weeds in this system for growing up as because of shifting in strip-tilled non-puddled condition from conventional puddled cultivation system (Zahan et al., 2014). This is the consequence of tillage that has a great influence on weed composition (Mishra and Singh, 2012) and moreover, minimum tillage usually alters species diversity (Murphy et al., 2006).

Traditionally weeds are managed by hand weeding. But, now-a-days, labour availability is decreasing with increasing wage, especially during the period of peak demand, is making manual weeding almost impossble for controlling weeds (Krishna et al., 2012). To overcome this situation, farmers are switching from manual weeding to herbicidal weed control (Hossain, 2015; Hasanuzzaman et al., 2008 ) as it is quick, effective and low cost weed control method (Kumar et al., 2008; Mahajan et al., 2002). Mazid (2001) reported that use of pre-emergence herbicides reduced the weeding cost by $38-46 \%$ compared with manual weeding in puddled transplanted rice, but thereafter only partial weed control can be achieved.

Available rice herbicides of our country are usually recommended for puddled transplanting system. The effectivity of those herbicides might have some divergence to control diversified weed species of strip-tilled non-puddled transplanted rice. Therefore, the present study was conducted to evaluate the effect of commonly used pre- and post-emergence rice herbicides on weeds and crop under strip tilled non-puddled transplanting condition.

\section{Materials and Methods}

The study was conducted at the Agronomy Field Laboratory, Department of Agronomy, Bangladesh Agricultural University, Mymensingh $\left(24^{0} 75^{\prime} \mathrm{N}\right.$ latitude and $90^{\circ} 50^{\prime} \mathrm{E}$ longitude in the south-west part of the old Brahmaputra plain). The experimental site was a medium-high land with sandy clay loam texture $(50 \%$ sand, $23 \%$ silt, $27 \%$ clay) and $\mathrm{pH}$ 7.2. The mean monthly maximum and minimum air temperatures were 29.5 and $23.1^{\circ} \mathrm{C}$, and 29.6 and $23.4^{\circ} \mathrm{C}$ recorded 
during the growing seasons of 2013 and 2014, respectively. The highest air temperature was recorded in July (maximum $32.3^{\circ} \mathrm{C}$ and minimum $26.8^{\circ} \mathrm{C}$ in 2013 and maximum $32.5^{\circ} \mathrm{C}$ and minimum $26.7^{\circ} \mathrm{C}$ in 2014). Temperature declined gradually from July to November $\left(29.6\right.$ to $\left.23.1^{\circ} \mathrm{C}\right)$ during both years. The total rainfall received during the cropping period (June to November) was $1287 \mathrm{~mm}$ in 2013 and $1625 \mathrm{~mm}$ in 2014. Sufficient rain water was available in 2013 during transplantation and establishment of rice due to heavy rainfall in July $(339 \mathrm{~mm})$. In 2014, comperatively less rainfall $(300 \mathrm{~mm})$ was recorded in the month of July than 2013 but no additional irrigation was required at that period for rice transplantation and seedling establishment. The highest rainfall of 2014 was recorded in the month of August (568.6 mm).

In the study, ten weed control treatments viz. $T_{1}=$ weedy check, $T_{2}=$ Weed-free check (four manual weedings done at 20,35, 50 and 65 days after transplanting), $\mathrm{T}_{3}=$ Pyrazosulfuron-ethyl fb (followed by) hand weeding (HW) at 25 days after transplanting $(\mathrm{DAT}), \mathrm{T}_{4}=$ Butachlor fb HW at $25 \mathrm{DAT}, \mathrm{T}_{5}=$ Pyrazosulfuronethyl $\mathrm{fb}$ acetochlor + bensulfuron methyl, $\mathrm{T}_{6}=$ Butachlor $\mathrm{fb}$ acetochlor + bensulfuron methyl, $\mathrm{T}_{7}=$ Pyrazosulfuron-ethyl fb orthosulfamuron fb butachlor + propanil, $\mathrm{T}_{8}=$ Butachlor $\mathrm{fb}$ orthosulfamuron fb butachlor + propanil, $\mathrm{T}_{9}=$ Pyrazosulfuron-ethyl $\mathrm{fb}$ orthosulfamuron $\mathrm{fb}$ 2,4-Damine, $\mathrm{T}_{10}=$ Butachlor $\mathrm{fb}$ orthosulfamuron $\mathrm{fb}$ 2,4-D amine during the first year and fifteen treatments viz. $\mathrm{T}_{1}=$ weedy check, $\mathrm{T}_{2}=$ Weed-free check, $\mathrm{T}_{3}=$ Pyrazosulfuron-ethyl, $\mathrm{T}_{4}=$ Butachlor, $\mathrm{T}_{5}=$ Orthosufamuron, $\mathrm{T}_{6}=$ Pyrazosulfuron-ethyl fb butachlor + propanil, $\mathrm{T}_{7}=$ Butachlor $\mathrm{fb}$ butachlor + propanil, $\mathrm{T}_{8}=$ Orthosulfamuron $\mathrm{fb}$ butachlor + propanil, $\mathrm{T}_{9}=$ Pyrazosulfuron-ethyl fb 2,4-D amine, $\mathrm{T}_{10}=$ Butachlor fb 2,4-D amine, $\mathrm{T}_{11}=$ Orthosulfamuron $\mathrm{fb}$ 2,4-D amine, $\mathrm{T}_{12}=$ Pyrazosulfuronethyl $\mathrm{fb}$ orthosulfamuron $\mathrm{fb}$ butachlor + propanil, $\mathrm{T}_{13}=$ Butachlor $\mathrm{fb}$ orthosulfamuron $\mathrm{fb}$ butachlor + propanil, $\mathrm{T}_{14}=$ Pyrazosulfuron-ethyl $\mathrm{fb}$ orthosulfamuron $\mathrm{fb}$ 2,4-D amine and $\mathrm{T}_{15}=$ Butachlor fb orthosulfamuron $\mathrm{fb}$ 2,4$\mathrm{D}$ amine during the second year were studied. The experiment was laid out in a randomized complete block design with three replications. In 2013, acetochlor + bensulfuron methyl (proprietary mixture) herbicide had phytotoxic effect on rice; therefore this herbicide was discarded in 2014. The chemical name, mode of action, time and dose of application of all tested herbicides are given in Table 1.

Before starting the experiment, the existing weeds of the field were initially killed by application of pre-planting non-selective herbicide, Roundup ${ }^{\circledR}$ (glyphosate $41 \%$ SL- IPA salt) @ $75 \mathrm{~mL} / 10 \mathrm{~L}$ water $\left(2.25 \mathrm{~L} \mathrm{ha}^{-1}\right)$ on 12 July 2013 and 10 July 2014. After one week, strip tillage was done in the field by Versatile Multi-Crop Planter (VMP) maintaining $20 \mathrm{~cm}$ line spacing (Haque et al., 2016). The land was fertilized with phosphorus, potassium, sulphur and zinc @ 20,35, 10 and $1.5 \mathrm{~kg} \mathrm{ha}^{-1}$ as triple super phosphate, muriate of potash, gypsum and $\mathrm{ZnSO}_{4}$, respectively just before strip-tilled the field. Then, land was inundated to 3-5 cm depth of standing water for 48 hours. After two days, 25day-old rice seedlings of $\mathrm{cv}$. BINA dhan-7 were transplanted at $15 \mathrm{~cm}$ spacing 
between hills aparted from $20 \mathrm{~cm}$ strips allocating three seedlings per hill. Nitrogen was applied @ $70 \mathrm{~kg} \mathrm{~N} \mathrm{ha}^{-1}$ as urea into two installments, at 7 and 35 days after transplanting (DAT). Herbicides were applied by hand operated knapsack sprayer fitted with flat-fan nozzle at a spray volume of $300 \mathrm{~L} \mathrm{ha}^{-1}$.

Table 1. Mode of action, time and rate of application of herbicides used in the experiment during 2013 and 2014

\begin{tabular}{|c|c|c|c|}
\hline Herbicides & $\begin{array}{c}\text { Time of } \\
\text { application }\end{array}$ & Mode of action & Recommended dose \\
\hline Pyrazosulfuron-ethyl & 3 DAT & $\begin{array}{l}\text { Inhibitor of } \\
\text { acetolactate synthase } \\
\text { (ALS) }\end{array}$ & $150 \mathrm{~g} \mathrm{ha}^{-1}\left(100 \mathrm{~g} \mathrm{ai} \mathrm{kg}^{-1}\right)$ \\
\hline Butachlor & 3 DAT & $\begin{array}{l}\text { Inhibitor of } \\
\text { microtubule assembly }\end{array}$ & $25 \mathrm{~kg} \mathrm{ha}^{1}\left(50 \mathrm{~g}\right.$ ai kg$\left.{ }^{-1}\right)$ \\
\hline Orthosulfamuron & 13 DAT & Inhibitor of ALS & 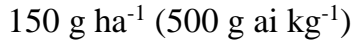 \\
\hline $\begin{array}{l}\text { Acetochlor + bensulfuron } \\
\text { methyl }^{*}\end{array}$ & $23 \mathrm{DAT}$ & $\begin{array}{l}\text { Inhibitor of cell } \\
\text { division and ALS }\end{array}$ & $300 \mathrm{~g} \mathrm{ac}^{-1}(100 \mathrm{~g}$ ai kg-1 $)$ \\
\hline Butachlor + propanil ${ }^{*}$ & $23 \mathrm{DAT}$ & $\begin{array}{l}\text { Inhibitor of very } \\
\text { long-chain fatty acid } \\
\text { synthesis and } \\
\text { photosynthesis at } \\
\text { photosystem II site A }\end{array}$ & $1 \mathrm{~L} \mathrm{ha}^{-1}\left(700 \mathrm{~mL} \mathrm{ai} \mathrm{L}^{-1}\right)$ \\
\hline 2,4-D amine & 23 DAT & Synthetic auxin & 2.25 $\mathrm{L} \mathrm{ha}^{-1}\left(720 \mathrm{~g}\right.$ ai L $\left.\mathrm{L}^{-1}\right)$ \\
\hline
\end{tabular}

'DAT' means 'days after transplanting', 'ai' means 'active ingradient', * = Proprietary mixture

Weed density and biomass were taken from three randomly selected quadrats of $0.25 \mathrm{~m}^{2}(50 \mathrm{~cm} \times 50 \mathrm{~cm})$ each at 20,35 and 50 DAT (data at 20 and 50 DAT were not presented as these were less well correlated with grain yield) to evaluate the efficacy of herbicides. The weed density was counted in plants $\mathrm{m}^{-2}$ and the weed dry matter was recorded in $\mathrm{g} \mathrm{m}^{-2}$ after oven drying the samples at $70{ }^{\circ} \mathrm{C}$ for $72 \mathrm{hrs}$. Weed control efficiency (WCE) and weed control index (WCI) were calculated using the equations of Devasenpathy et al. (2008).

$\mathrm{WCE}(\%)=\frac{\mathrm{WPc}-\mathrm{WPt}}{\mathrm{WPc}} \times 100$ Where, $W P_{c}=$ Weed population $\left(\right.$ no. $\left.\mathrm{m}^{-2}\right)$ in control (weedy) plot and $W P_{t}=$ Weed population $\left(\right.$ no. $\mathrm{m}^{-2}$ ) in treated plot

WCI $(\%)=\frac{\text { DMPc-DMPt }}{\text { DMPc }} \times 100$ Where, DMP $_{c}=$ Weed dry matter production in control plot and $\mathrm{DMP}_{\mathrm{t}}=$ Weed dry matter production in treated plot 
Plant height and yield attributing characters were recorded from five randomly selected hills before harvesting the whole plot. Grain and straw yields were recorded by harvesting the crop from the central area $6 \mathrm{~m}^{2}(2 \mathrm{~m} \times 3 \mathrm{~m})$ area of the plot and grain yield was adjusted at $14 \%$ moisture level. Percent yield increase over control (YOC) was calculated by the following formula (Devasenpathy et al., 2008).

YOC $(\%)=\frac{T Y-W Y}{W Y} \times 100$ Where, $T Y=$ Grain yield in weed control treatment and $W Y=$ Grain yield in weedy treatment

Economic analysis was carried out to determine the cost-effectiveness of different herbicide treatments following the procedure by Parvez et al. (2013). Four manual weeding operations were considered sufficient to keep the plots weed-free throughout the growing season. Labour required for one manual weeding and one herbicide spraying $\mathrm{ha}^{-1}$ area were 25 and 2 person day ${ }^{-1}$, respectively. The cost required for one labour was Taka 250 day $^{-1}$. Herbicide requirement was calculated by the amount of commercial product ha ${ }^{-1}$ and the cost of each herbicide was calculated based on their local market price. The net return $\mathrm{ha}^{-1}$ for each treatment was calculated by deducting the total cost (fixed cost + weed management cost) from the gross return.

Data were subjected to analysis of variance (ANOVA) and means were compared by Tukeys's Honest Significant Difference (HSD) test at $\mathrm{P}<0.05$ using statistical package program 'Statistical Tool for Agricultural Research (STAR) nebula' developed by International Rice Research Institute (version 2.0.1, January 2014).

\section{Results and Discussion}

\section{Distribution and density of weed species}

Seven major weed species were identified in the strip tilled non-puddled transplanted rice field at 35 days after transplanting (DAT) during both years (Table 2). Among those weeds, two were grass (Cynodon dactylon and Echinochloa colona), three sedges (Cyperus rotundus, Fimbristylis miliacea and Cyperus difformis) and two broad leaf weeds (Ludwigia decurrens and Cyanotis axillaris). Besides those, some other weed species like Leersia hexandra, Dactyloctenium aegyptium, Monochoria vaginalis, Commelina benghalensis and Cyperus iria were present during 2013 at a very low density while those minor species were completely absent in 2014. Similar weed species composition in non-puddled field was also reported by Chhokar et al. (2014) and Timsina et al. (2010) but they conducted their study on direct seeded rice (DSR). However, the present study has identified some weed species in transplanted aman rice under strip-tilled non-puddled field condition that might be different in different location and soil type. Moreover, only continued for two consecutive years, it is 
too early to conclude weed species composition and diversity type under this reduced tillage system.

The study demonstrated that the highest densities of all the weed species were recorded from the weedy check while herbicide treatments significantly $(\mathrm{P}<0.001)$ reduced the densities of all the weed species during both the year (Table 2). Results also showed that densities of all weed species in 2014 were 30$75 \%$ less in number compared to the preceeding year except $F$. miliacea that remained similar in number as it was in 2013 (Table 2).

Among grass weeds, relative to that high density of weedy plots, herbicide treated plots reduced $C$. dactylon by $66-87 \%$ in 2013 and $24-94 \%$ in 2014 , whereas in case of E. colona, this reduction was by $45-100 \%$ in 2013 and 44$100 \%$ in 2014 . Complete density reduction of E. colona in 2013 was provided by the treatment having pyrazosulfuron-ethyl as pre-emergence herbicide followed by acetochlor + bensulfuron methyl or followed by orthosulfamuron and butachlor + propanil / 2,4-D amine (Table 2). In 2014, pyrazosulfuron-ethyl followed by orthosulfamuron followed by butachlor + propanil and orthosulfamuron followed by butachlor + propanil treatments reduced the density of E. colona completely. But, none of the herbicide treatments gave complete density reduction of $C$. dactylon during both years, perhaps, due to the regenerating capability from the viable stolon and branched underneath rhizome of this perennial weed. However, the greatest density reduction of $C$. dactylon in 2013 was provided by butachlor followed by one hand weeding at 25 DAT and pyrazosulfuron-ethyl followed by orthosulfamuron and butachlor + propanil. In 2014, pyrazosulfuron-ethyl followed by orthosulfamuron and butachlor + propanil and orthosulfamuron followed by butachlor + propanil treatments offered the highest reduction. On the other hand, the lowest density reduction of C. dactylon was in pyrazosulfuron-ethyl followed by acetochlor + bensulfuron methyl treated plots during 2013 and in butachlor followed by 2,4-D amine during 2014.

In case of sedge weeds, treatments having pyrazosulfuron-ethyl gave $100 \%$ density reduction of Cyperus rotundus, $F$. miliacea and $C$. difformis during both the year, however exception was found in sole application of pyrazosulfuronethyl and pyrazosulfuron-ethyl followed 2,4-D amine as these treatments provided $57 \%$ and $90 \%$ density reduction, respectively during 2014 . On the contrary, treatments with butachlor reduced the density of $C$. rotundus by 38$67 \%$ in 2013 and $52-100 \%$ in 2014; F. miliacea by $39-100 \%$ in 2013 and $50-80 \%$ in 2014; C. difformis by 76-100\% in 2013 and 50-90\% in 2014. Moreover, during 2014 , only butachlor followed by butachlor + propanil provided complete reduction of $C$. rotundus. In case of $F$. miliacea, complete reduction was obtained from butachlor followed by orthosulfamuron $\mathrm{fb}$ butachlor + propanil and butachlor followed by orthosulfamuron fb 2,4-D amine treatments during both years (Table 2). In case of $C$. difformis, only butachlor followed by acetochlor + bensulfuron methyl gave complete density reduction during 2013 but none of the herbicide treatments of 2014 provided 100\% reduction on the density of this species. In earlier studies, less effectivity of butachlor on sedges was also reported in DSR (Katherisan, 2001; Patra et al., 2006; Mahajan and Chauhan, 
2008). Moreover, Olofintoye and Mabbayad (1980) conducted an experiment on weed control of upland rice and also found that butachlor was a less effective herbicide to control sedge under minimum tillage system compared to the conventional tillage practice.

Table 2. Effect of herbicide treatments on absolute density (plants $\mathrm{m}^{-2}$ ) and relative reduction in density (\%, in parenthesis) of weed species in non-puddled transplanted rice at 35 days after transplanting during $2013^{\mathrm{a}}$ and $2014^{\mathrm{b}}$

\begin{tabular}{|c|c|c|c|c|c|c|c|c|}
\hline Treatment & \begin{tabular}{|l|} 
Cynodon \\
dactylon
\end{tabular} & $\begin{array}{c}\text { Echinochloa } \\
\text { colona }\end{array}$ & \begin{tabular}{|l|} 
Cyperus \\
rotundus
\end{tabular} & $\begin{array}{c}\text { Fimbristylis } \\
\text { miliacea }\end{array}$ & \begin{tabular}{|l|} 
Cyperus \\
difformis
\end{tabular} & $\begin{array}{l}\text { Ludwigia } \\
\text { decurrens }\end{array}$ & $\begin{array}{l}\text { Cyanotis } \\
\text { axillaris }\end{array}$ & Others \\
\hline \multicolumn{9}{|c|}{2013} \\
\hline $\mathrm{T}_{1}$ & $60(0)$ & $23(0)$ & $32(0)$ & $9(0)$ & $34(0)$ & $17(0)$ & $29(0)$ & $18(0)$ \\
\hline $\mathrm{T}_{3}$ & $15(75)$ & $1(94)$ & $0(100)$ & $0(100)$ & $0(100)$ & $0(100)$ & $15(47)$ & $5(74)$ \\
\hline $\mathrm{T}_{4}$ & $8(87)$ & $9(63)$ & $11(67)$ & $5(49)$ & $8(76)$ & $1(92)$ & $15(47)$ & $1(96)$ \\
\hline $\mathrm{T}_{5}$ & $20(67)$ & $0(100)$ & $0(100)$ & $0(100)$ & $0(100)$ & $0(100)$ & $11(61)$ & $1(96)$ \\
\hline $\mathrm{T}_{6}$ & $16(73)$ & $13(45)$ & $17(48)$ & $6(39)$ & $0(100)$ & $3(80)$ & $12(58)$ & $0(100)$ \\
\hline $\mathrm{T}_{7}$ & $10(83)$ & $0(100)$ & $0(100)$ & $0(100)$ & $0(100)$ & $0(100)$ & $3(91)$ & $0(100)$ \\
\hline $\mathrm{T}_{8}$ & $14(77)$ & $9(60)$ & $20(38)$ & $0(100)$ & $5(84)$ & $2(86)$ & $4(86)$ & $1(96)$ \\
\hline $\mathrm{T}_{9}$ & $14(77)$ & $0(100)$ & $0(100)$ & $0(100)$ & $0(100)$ & $0(100)$ & $0(100)$ & $0(100)$ \\
\hline $\mathrm{T}_{10}$ & $17(72)$ & $3(86)$ & $13(60)$ & $0(100)$ & $7(79)$ & $0(100)$ & $0(100)$ & $0(100)$ \\
\hline $\mathrm{HSD}_{0.05}$ & 4.59 & 2.59 & 2.99 & 1.54 & 2.54 & 2.62 & 3.71 & 2.05 \\
\hline $\mathrm{CV}(\%)$ & 13.76 & 22.92 & 16.94 & 40.60 & 24.13 & 57.51 & 21.75 & 69.40 \\
\hline \multicolumn{9}{|c|}{2014} \\
\hline $\mathrm{T}_{1}$ & $40(0)$ & $11(0)$ & $8(0)$ & $10(0)$ & $9(0)$ & $11(0)$ & $15(0)$ & - \\
\hline $\mathrm{T}_{3}$ & $17(59)$ & $6(45)$ & $0(100)$ & $0(100)$ & $4(57)$ & $5(58)$ & $6(60)$ & - \\
\hline $\mathrm{T}_{4}$ & $22(46)$ & $6(45)$ & $4(52)$ & $3(73)$ & $4(57)$ & $9(15)$ & $9(38)$ & - \\
\hline $\mathrm{T}_{5}$ & $5(88)$ & $4(65)$ & $0(100)$ & $0(100)$ & $4(57)$ & $0(100)$ & $0(100)$ & - \\
\hline $\mathrm{T}_{6}$ & $5(88)$ & $4(65)$ & $0(100)$ & $0(100)$ & $0(100)$ & $0(100)$ & $2(87)$ & - \\
\hline $\mathrm{T}_{7}$ & $6(85)$ & $5(53)$ & $0(100)$ & $2(80)$ & $3(64)$ & $3(70)$ & $5(67)$ & - \\
\hline $\mathrm{T}_{8}$ & $2(94)$ & $0(100)$ & $0(100)$ & $0(100)$ & $0(100)$ & $0(100)$ & $0(100)$ & - \\
\hline $\mathrm{T}_{9}$ & $24(40)$ & $5(53)$ & $0(100)$ & $0(100)$ & $1(90)$ & $0(100)$ & $3(78)$ & - \\
\hline $\mathrm{T}_{10}$ & $31(24)$ & $6(45)$ & $2(76)$ & $5(50)$ & $4(57)$ & $0(100)$ & $5(67)$ & - \\
\hline $\mathrm{T}_{11}$ & $3(93)$ & $3(76)$ & $0(100)$ & $0(100)$ & $2(75)$ & $0(100)$ & $0(100)$ & - \\
\hline $\mathrm{T}_{12}$ & $2(94)$ & $0(100)$ & $0(100)$ & $0(100)$ & $0(100)$ & $0(100)$ & $0(100)$ & - \\
\hline $\mathrm{T}_{13}$ & $3(93)$ & $2(82)$ & $2(76)$ & $0(100)$ & $1(90)$ & $0(100)$ & $3(78)$ & \\
\hline $\mathrm{T}_{14}$ & $14(65)$ & $2(82)$ & $0(100)$ & $0(100)$ & $0(100)$ & $0(100)$ & $0(100)$ & \\
\hline $\mathrm{T}_{15}$ & $21(49)$ & $3(76)$ & $2(76)$ & $0(100)$ & $5(50)$ & $0(100)$ & $1(96)$ & \\
\hline $\mathrm{HSD}_{0.05}$ & 4.90 & 2.65 & 2.58 & 1.94 & 2.74 & 2.23 & 3.21 & - \\
\hline CV (\%) & 20.10 & 34.94 & 103.71 & 73.18 & 54.09 & 52.14 & 46.70 & - \\
\hline
\end{tabular}

${ }^{a} T_{1}=$ Weedy check; $T_{3}=$ Pyrazosulfuron-ethyl followed by $(\mathrm{fb})$ hand weeding $(H W)$ at 25DAT; $T_{4}=$ Butachlor fb HW at $25 \mathrm{DAT} ; T_{5}=$ Pyrazosulfuron-ethyl fb acetochlor + bensulfuron methyl; $T_{6}=$ Butachlor $\mathrm{fb}$ acetochlor + bensulfuron methyl; $T_{7}=$ Pyrazosulfuron-ethyl $\mathrm{fb}$ orthosulfamuron $\mathrm{fb}$ butachlor + propanil; $T_{8}=$ Butachlor $\mathrm{fb}$ orthosulfamuron $\mathrm{fb}$ butachlor + propanil; $T_{9}=$ Pyrazosulfuron-ethyl fb orthosulfamuron $f b$ 2,4-D amine and $T_{10}=$ Butachlor fb orthosulfamuron $f b$ 2,4-D amine.

${ }^{b} T_{1}=$ Weedy check; $T_{3}=$ Pyrazosulfuron ethyl; $T_{4}=$ Butachlor; $T_{5}=$ Orthosulfamuron $;$ $T_{6}=$ Pyrazosulfuron ethyl fb butachlor + propanil; $T_{7}=$ Butachlor fb butachlor + propanil; $T_{8}=$ Orthosulfamuron fb butachlor + propanil; $T_{9}=$ Pyrazosulfuron ethyl fb 2,4-D amine; $T_{10}=$ Butachlor fb 2,4-D amine; $T_{11}=$ Orthosulfamuron fb 2,4-D amine; $T_{12}=$ Pyrazosulfuron ethyl fb orthosulfamuron fb butachlor + propanil; $T_{13}=$ Butachlor $f b$ orthosulfamuron $f b$ butachlor + propanil; $T_{14}=$ Pyrazosulfuron ethyl fb orthosulfamuron $f b$ 2,4-D and $T_{15}=$ Butachlor $f b$ orthosulfamuron fb 2,4-D amine. 
In case of broadleaf weeds, pyrazosulfuron-ethyl having all treatments provided full control of Ludwigia decurrens in both years (Table 2). Moreover, butachlor followed by orthosulfamuron followed by 2,4-D amine also ensured complete control of this species during both the year whereas butachlor followed by orthosulfamuron followed by butachlor + propanil was also offered full control of this broadleaf weed in 2014. In case of Cyanotis axillaris, pyrazosulfuronethyl followed by (fb) orthosulfamuron $\mathrm{fb}$ 2,4-D amine and butachlor $\mathrm{fb}$ orthosulfamuron fb butachlor + propanil gave complete control in 2013. During 2014, orthosulfamuron, orthosulfamuron $\mathrm{fb}$ butachlor + propanil, orthosulfamuron $\mathrm{fb}$ 2,4-D amine, pyrazosulfuron-ethyl $\mathrm{fb}$ orthosulfamuron $\mathrm{fb}$ butachlor + propanil and pyrazosulfuron-ethyl $\mathrm{fb}$ orthosulfamuron $\mathrm{fb}$ 2,4-D amine fully controlled this species. Previous study also found sequential herbicide treatments including post-emergence herbicide were effective for broadleaf weed control (Chauhan et al., 2015). But, the study showed less $C$. axillaris control efficiency of acetochlor + bensulfuron methyl compared to other post-emergence herbicides that is consistent with the previous study of Ahmed and Chauhan (2014) where this herbicide was also less effective on broadleaf weed in DSR.

In case of other minor weed species, herbicide treatments reduced their densities by $74-100 \%$ compared to weedy check in 2013 and this species were totally absent in 2014.

\section{Total weed density and biomass}

Weedy check had the highest weed densities (222 and 105 plants $\mathrm{m}^{-2}$ in 2013 and 2014, respectively) and biomass (36.8 and $23.8 \mathrm{~g} \mathrm{~m}^{-2}$ in 2013 and 2014, respectively). This result clearly indicated that the weed density and biomass in 2014 were remarkably lower than the preceeding year by $53-55 \%$ (Table 3 ). This might be related to the practice of strip tilled non-puddled transplanting in rice followed by strip tillage plus residue retention in the succeeding crops (wheat and mungbean) of the rotation. Mishra and Singh (2012) also reported the decrease of weed biomass by three-fold in the second year compared to the first year in DSR under zero tillage system.

Herbicide treatments had significant effect on reduction of weed density and biomass during both years and this reduction was 70-94\% during 2013 and 4698\% during 2014 in case of weed density whereas in case of weed biomass, the reduction was recorded 56-94\% in 2013 and 43-95\% in 2014 compared to the weedy check (Table 3). Treatments with pyrazosulfuron-ethyl $\mathrm{fb}$ orthosulfamuron fb butachlor + propanil offered the highest weed control effiency (WCE) and weed control index (WCI) during both the year (Table 3). Pyrazosulfuron-ethyl $\mathrm{fb}$ orthosulfamuron $\mathrm{fb}$ 2,4-D amine was also ensured higher WCE and WCI compared to other treatments in both years. Chauhan (2012) 
reported that use of single herbicide could not provide effective weed control due to the presence of the complex mixture of the weed species in the field. With sequential application of herbicides different weed species can control effectively, but use of herbicides with different modes of action is advisable to avoid herbicide resistence development in weeds (Busi et al., 2014; Owen and Powles, 2009). On the contrary, the lowest WCE and WCI were obtained from butachlor fb acetochlor + bensulfuron methyl in 2013 and in 2014, from sole application of butachlor. This lower weed controlling efficiency of butachlor might be related to the less control of Echinochloa colona and Cyperus rotundus at 35 DAT (Table 2). Moreover, acetochlor + bensulfuron methyl had poor control on on broadleaf weeds. Similar result was also by Halder et al. (2005) that pyrazosulfuron-ethyl @ 15g a.i ha ${ }^{-1}$ reduced weed density and biomass more than butachlor @ 750g a.i ha ${ }^{-1}$ while both herbicides were applied at 4 days after transplanting of rice, however the study was conducted in puddled field condition.

\section{Height of rice plant}

Plant height of transplanted aman rice was significantly affected by herbicides during both years (Table 4). Results demonstrated that the highest plant height in 2013 was recorded from butachlor fb hand weeding at 25 DAT $(108.5 \mathrm{~cm})$, and in 2014, the highest height was obtained from orthosulfamuron $(111.7 \mathrm{~cm})$ whereas weed-free plots had plant height of $104.5 \mathrm{~cm}$ in 2013 and $108.7 \mathrm{~cm}$ in 2014. The lowest plant height of 2013 was in butachlor $\mathrm{fb}$ acetochlor + bensulfuron methyl which was closely followed by pyrazosulfuron-ethyl $\mathrm{fb}$ acetochlor + bensulfuron methyl. During 2014, the lowest plant height was recorded from weedy plots.

\section{Number of panicles $\mathbf{m}^{-2}$ and filled grains panicle ${ }^{-1}$}

Number of panicles $\mathrm{m}^{-2}$ and number of filled grains panicle ${ }^{-1}$ of strip-tilled non-puddled transplanted rice were significantly affected by herbicide treatments during 2013 and 2014 (Table 4). In 2013, the highest numbers of panicles $\mathrm{m}^{-2}$ and filled grains panicle ${ }^{-1}$ were counted from weed-free plots and identical results were also obtained from pyrazosulfuron-ethyl $\mathrm{fb}$ orthosulfamuron $\mathrm{fb}$ butachlor + propanil treated plots. Butachlor $\mathrm{fb}$ orthosulfamuron $\mathrm{fb}$ butachlor + propanil also provided similar number of panicles $\mathrm{m}^{-2}$ and pyrazosulfuron-ethyl fb orthosulfamuron $\mathrm{fb}$ 2,4-D amine gave similar number of filled grains panicle ${ }^{-1}$ with weed-free control. This might be happened for ensuring better weed control by those treatment that leads to reduced crop-weed competition and facilitated the uptake of more nutrients resulted healthier rice plants with more tillers and panicles (Ahmed and Chauhan, 2014; Awan et al., 2014). 
Table 3. Effect of herbicide treatments on weed density and biomass and their weed control efficiency (WCE) and weed control index (WCI) in strip-tilled nonpuddled transplanted rice field at 35 days after during 2013 and 2014

\begin{tabular}{|c|c|c|c|c|}
\hline Treatments & $\begin{array}{l}\text { Weed density } \\
\left(\text { no. } \mathrm{m}^{-2}\right)\end{array}$ & $\begin{array}{l}\text { WCE } \\
(\%)\end{array}$ & $\begin{array}{l}\text { Weed biomass } \\
\left(\mathrm{g} \mathrm{m}^{-2}\right)\end{array}$ & $\begin{array}{l}\text { WCI } \\
(\%)\end{array}$ \\
\hline & \multicolumn{4}{|c|}{2013} \\
\hline Weedy check & 222 & - & 36.8 & - \\
\hline Pyrazosulfuron-ethyl fb HW at 25 DAT & 36 & 84 & 4.6 & 88 \\
\hline Butachlor fb HW at 25 DAT & 56 & 75 & 5.2 & 86 \\
\hline Pyrazosulfuron-ethyl fb aceto + bensul & 32 & 85 & 10.5 & 72 \\
\hline Butachlor fb aceto + bensul & 66 & 70 & 16.6 & 56 \\
\hline $\begin{array}{l}\text { Pyrazosulfuron-ethyl fb orthosul fb } \\
\text { buta + prop }\end{array}$ & 13 & 94 & 2.2 & 94 \\
\hline Butachlor fb orthosul fb buta + prop & 56 & 75 & 6.3 & 83 \\
\hline $\begin{array}{l}\text { Pyrazosulfuron-ethyl fb orthosul fb 2,4- } \\
\text { D }\end{array}$ & 14 & 94 & 2.5 & 93 \\
\hline Butachlor fb orthosul fb 2,4-D & 40 & 82 & 6.6 & 82 \\
\hline $\mathrm{HSD}_{0.05}$ & 6.95 & & 1.42 & \\
\hline \multirow[t]{2}{*}{ CV (\%) } & 7.79 & & 9.90 & \\
\hline & \multicolumn{4}{|c|}{2014} \\
\hline Weedy check & 105 & - & 23.8 & - \\
\hline Pyrazosulfuron-ethyl & 37 & 65 & 10.1 & 58 \\
\hline Butachlor & 57 & 46 & 13.6 & 43 \\
\hline Orthosul & 13 & 88 & 7.0 & 71 \\
\hline Pyrazosulfuron-ethyl fb buta + prop & 11 & 90 & 4.2 & 82 \\
\hline Butachlor fb buta + prop & 25 & 76 & 6.1 & 74 \\
\hline Orthosul fb buta + prop & 2 & 98 & 1.9 & 92 \\
\hline Pyrazosulfuron-ethyl fb 2,4-D & 33 & 68 & 6.4 & 73 \\
\hline Butachlor fb 2,4-D & 54 & 49 & 8.1 & 66 \\
\hline Orthosul fb 2,4-D & 8 & 92 & 5.0 & 79 \\
\hline $\begin{array}{l}\text { Pyrazosulfuron-ethyl fb orthosul fb } \\
\text { buta + prop }\end{array}$ & 2 & 98 & 1.2 & 95 \\
\hline Butachlor fb orthosul fb buta + prop & 11 & 90 & 3.6 & 85 \\
\hline $\begin{array}{l}\text { Pyrazosulfuron-ethyl fb orthosul fb 2,4- } \\
\text { D }\end{array}$ & 16 & 85 & 3.3 & 86 \\
\hline Butachlor fb orthosul fb 2,4-D & 31 & 71 & 4.9 & 79 \\
\hline $\mathrm{HSD}_{0.05}$ & 8.26 & & 2.29 & \\
\hline $\mathrm{CV}(\%)$ & 9.48 & & 10.75 & \\
\hline
\end{tabular}

' $\mathrm{fb}$ ' = 'followed by', 'aceto + bensul' = 'acetochlor + bensulfuron methyl', 'orthosul' = 'orthosulfamuron', 'buta + prop' = 'butachlor + propanil', '2,4-D' = '2,4-D amine', ' $\mathrm{CV}$ ' $=$ co-efficient of variance 


\section{Rice grain and straw yield}

Grain and straw yield of T. aman rice was significantly influenced by the application of different weed control treatments (Table 5). In both years, the lowest grain and straw yields were in weedy control whereas weed-free control produced the highest grain and straw yield in 2013, and in 2014, the highest yields were recorded from pyrazosulfuron-ethyl fb orthosulfamuron fb butachlor + propanil. Moreover, this treatment and butachlor $\mathrm{fb}$ orthosulfamuron $\mathrm{fb}$ butachlor + propanil also provided similar higher grain yield as weed-free control in 2013. During 2014, pyrazosulfuron-ethyl fb orthosulfamuron fb 2,4-D amine, butachlor $\mathrm{fb}$ orthosulfamuron $\mathrm{fb}$ butachlor + propanil and orthosulfamuron $\mathrm{fb}$ butachlor + propanil produced similar grain and straw yield with weed-free control. The increase in yield with herbicides owed the significant reduction in density and dry matter of weeds which were unable to compete with the crop plants for different growth factors which consequently resulted in the better expression of yield components and thus gave higher yield of rice. Awan et al. (2015) and Zahan et al. (2014) reported that sequential application of preemergence, early post- and late-post-emergence herbicides effectively controlled weeds during the whole crop growth stage and therefore higher yield was achieved.

\section{Economic analysis}

Partial economic analysis results revealed that the lowest gross income and net benefit were calculated from the weedy check in both years. Results also showed that weed-free treatment had the highest gross income in 2013 but the highest net return was calculated from pyrazosulfuron-ethyl fb orthosulfamuron fb butachlor + propanil. The reason might be the high weed management cost involment of weed-free plots that reduced the amount of net return compared to the pyrazosulfuron-ethyl fb orthosulfamuron fb butachlor + propanil treatment. In 2013, except pyrazosulfuron-ethyl fb acetochlor + bensulfuron methyl and butachlor fb acetochlor + bensulfuron methyl, all other herbicide treatments had higher economic return by 5.6-43.1\% over weed-free treatment (Table 5). In 2014, the highest gross income and net return were also calculated from pyrazosulfuron-ethyl fb orthosulfamuron $\mathrm{fb}$ butachlor + propanil. Treatments that also had higher net benefit over weed-free control treatment in 2014 were pyrazosulfuron-ethyl $\mathrm{fb}$ orthosulfamuron $\mathrm{fb}$ 2,4-D amine > butachlor $\mathrm{fb}$ orthosulfamuron $\mathrm{fb}$ butachlor + propanil $>$ orthosulfamuron fb butachlor + propanil > pyrazosulfuron-ethyl fb butachlor + propanil $>$ butachlor $\mathrm{fb}$ orthosulfamuron $\mathrm{fb}$ 2,4-D amine > orthosulfamuron $\mathrm{fb}$ 2,4-D amine. This findings are in support with several previos researches that also reported high weeding cost made weed-free treatment economically non-profitable (Parvez et al., 2013). 
Table 4. Effect of herbicide treatments on plant height, number of panicles $\mathrm{m}^{-2}$ and filled grains panicle ${ }^{-1}$ of transplanted aman rice in non-npuddled soil during 2013 and 2014

\begin{tabular}{|c|c|c|c|}
\hline Treatments & $\begin{array}{l}\text { Plant height } \\
(\mathrm{cm})\end{array}$ & $\begin{array}{c}\text { Panicles } \mathrm{m}^{-2} \\
\text { (No.) }\end{array}$ & $\begin{array}{l}\text { Filled grains } \\
\text { panicle }^{-1} \text { (No.) }\end{array}$ \\
\hline & \multicolumn{3}{|c|}{2013} \\
\hline Weedy check & 103.9 & 339 & 58.0 \\
\hline Weed-free check & 104.5 & 429 & 74.7 \\
\hline Pyrazosulfuron-ethyl fb HW at 25 DAT & 105.7 & 371 & 72.1 \\
\hline Butachlor fb HW at 25 DAT & 108.5 & 358 & 68.1 \\
\hline Pyrazosulfuron-ethyl fb aceto + bensul & 95.9 & 401 & 59.6 \\
\hline Butachlor fb aceto + bensul & 95.3 & 340 & 52.2 \\
\hline $\begin{array}{l}\text { Pyrazosulfuron-ethyl fb orthosul fb buta }+ \\
\text { prop }\end{array}$ & 104.5 & 412 & 73.2 \\
\hline Butachlor fb orthosul fb buta + prop & 104.1 & 409 & 70.3 \\
\hline $\begin{array}{l}\text { Pyrazosulfuron-ethyl fb orthosul fb 2,4-D } \\
\text { amine }\end{array}$ & 103.1 & 352 & 74.4 \\
\hline Butachlor fb orthosul fb 2,4-D amine & 102.0 & 350 & 73.0 \\
\hline $\mathrm{HSD}_{0.05}$ & 1.76 & 31.63 & 2.62 \\
\hline \multirow[t]{2}{*}{$\mathrm{CV}(\%)$} & 1.12 & 4.90 & 2.26 \\
\hline & \multicolumn{3}{|c|}{2014} \\
\hline Weedy check & 107.0 & 316 & 50.2 \\
\hline Weed-free check & 108.7 & 409 & 92.3 \\
\hline Pyrazosulfuron-ethyl & 110.3 & 352 & 71.2 \\
\hline Butachlor & 110.6 & 334 & 63.9 \\
\hline Orthosul & 111.7 & 342 & 65.0 \\
\hline Pyrazosulfuron-ethyl fb buta + prop & 108.9 & 386 & 79.5 \\
\hline Butachlor fb buta + prop & 109.1 & 374 & 67.8 \\
\hline Orthosul fb buta + prop & 109.3 & 370 & 76.5 \\
\hline Pyrazosulfuron-ethyl fb 2,4-D amine & 108.7 & 353 & 62.2 \\
\hline Butachlor fb 2,4-D amine & 108.3 & 348 & 60.2 \\
\hline Orthosul fb 2,4-D amine & 107.2 & 348 & 66.2 \\
\hline $\begin{array}{l}\text { Pyrazosulfuron-ethyl fb orthosul fb buta }+ \\
\text { prop }\end{array}$ & 109.2 & 425 & 94.8 \\
\hline Butachlor fb orthosul fb buta + prop & 107.2 & 385 & 81.6 \\
\hline $\begin{array}{l}\text { Pyrazosulfuron-ethyl fb orthosul fb 2,4-D } \\
\text { amine }\end{array}$ & 107.8 & 391 & 85.2 \\
\hline Butachlor fb orthosul fb 2,4-D amine & 109.1 & 368 & 75.8 \\
\hline $\mathrm{HSD}_{0.05}$ & 2.85 & 41.75 & 11.11 \\
\hline $\mathrm{CV}(\%)$ & 7.89 & 3.76 & 5.04 \\
\hline
\end{tabular}

' $\mathrm{fb}$ ' = 'followed by', 'aceto + bensul' = 'acetochlor + bensulfuron methyl', 'orthosul' = 'orthosulfamuron', 'buta + prop' = 'butachlor + propanil', '2,4-D' = '2,4-D amine', CV = co-efficient of variance 
Table 5. Effect of herbicides on grain and straw yield and their cost effectiveness in strip-tilled non-puddled transplanted aman rice in 2013 and 2014

\begin{tabular}{|c|c|c|c|c|c|c|}
\hline Treatments & $\begin{array}{c}\text { Grain } \\
\text { yield } \\
\left(\mathrm{t} \mathrm{ha}^{-1}\right)\end{array}$ & $\begin{array}{c}\text { Straw } \\
\text { yield } \\
\left(\mathrm{t} \mathrm{ha}^{-1}\right)\end{array}$ & $\begin{array}{c}\text { Weed } \\
\text { management } \\
\text { cost }\left(\mathrm{Tk} \cdot \mathrm{ha}^{-1}\right)\end{array}$ & $\begin{array}{l}\text { Total cost } \\
\left(\mathrm{Tk} . \mathrm{ha}^{-1}\right)\end{array}$ & \begin{tabular}{|c|} 
Gross \\
income \\
$\left(\mathrm{Tk} \cdot \mathrm{ha}^{-1}\right)$ \\
\end{tabular} & $\begin{array}{c}\text { Net } \\
\text { benefit } \\
\left(\mathrm{Tk} . \mathrm{ha}^{-1}\right)\end{array}$ \\
\hline \multicolumn{7}{|c|}{2013} \\
\hline Weedy check & 3.10 & 4.84 & 0 & 42125 & 59960 & 17835 \\
\hline Weed-free check & 5.51 & 6.54 & 25000 & 67125 & 103225 & 36100 \\
\hline Pyrazo fb HW & 4.76 & 5.98 & 7140 & 49265 & 89890 & 40625 \\
\hline Buta fb HW & 4.68 & 5.99 & 8300 & 50425 & 88545 & 38120 \\
\hline Pyrazo fb aceto + bensul & 3.83 & 5.32 & 2146 & 44271 & 73090 & 28819 \\
\hline Buta fb aceto + bensul & 3.44 & 5.23 & 3306 & 45431 & 66325 & 20894 \\
\hline $\begin{array}{l}\text { Pyrazo fb orthosul fb buta }+ \\
\text { prop }\end{array}$ & 5.42 & 6.17 & 3850 & 45975 & 101905 & 55930 \\
\hline $\begin{array}{l}\text { Buta fb orthosul fb buta }+ \\
\text { prop }\end{array}$ & 5.02 & 5.79 & 5010 & 47135 & 94025 & 46890 \\
\hline Pyrazo fb orthosul fb 2,4-D & 5.25 & 6.03 & 4515 & 46640 & 98295 & 51655 \\
\hline Buta fb orthosul fb 2,4-D & 4.98 & 5.80 & 5675 & 47800 & 93360 & 45560 \\
\hline $\mathrm{HSD}_{0.05}$ & 0.31 & 0.24 & - & - & - & - \\
\hline $\mathrm{CV}(\%)$ & 3.88 & 2.46 & - & - & - & - \\
\hline & \multicolumn{6}{|c|}{2014} \\
\hline Weedy check & 2.69 & 4.24 & 0 & 42125 & 52147 & 10022 \\
\hline Weed-free check & 5.99 & 6.36 & 25000 & 67125 & 111427 & 44302 \\
\hline Pyrazo & 3.58 & 5.11 & 890 & 43015 & 68463 & 25448 \\
\hline Buta & 3.20 & 4.69 & 2050 & 44175 & 61430 & 17255 \\
\hline Orthosul & 3.75 & 5.44 & 1550 & 43675 & 71910 & 28235 \\
\hline Pyrazo fb buta + prop & 5.30 & 5.68 & 2300 & 44425 & 98563 & 54138 \\
\hline Buta fb buta + prop & 4.42 & 5.14 & 3460 & 45585 & 82912 & 37327 \\
\hline Orthosul fb buta + prop & 5.67 & 6.04 & 2960 & 45085 & 105393 & 60308 \\
\hline Pyrazo fb 2,4-D & 4.68 & 5.42 & 2965 & 45090 & 87752 & 42662 \\
\hline Buta fb 2,4-D & 4.12 & 5.26 & 4125 & 46250 & 77935 & 31685 \\
\hline Orthosul fb 2,4-D & 4.84 & 5.44 & 3625 & 45750 & 90445 & 44695 \\
\hline $\begin{array}{l}\text { Pyrazo fb orthosul fb buta }+ \\
\text { prop }\end{array}$ & 6.18 & 6.61 & 3850 & 45975 & 115032 & 69057 \\
\hline $\begin{array}{l}\text { Buta fb orthosul fb buta }+ \\
\text { prop }\end{array}$ & 5.82 & 6.23 & 5010 & 47135 & 108228 & 61093 \\
\hline Pyrazo fb orthosul fb 2,4-D & 6.01 & 6.46 & 4515 & 46640 & 111865 & 65225 \\
\hline Buta fb orthosul fb 2,4-D & 4.95 & 5.82 & 5675 & 47800 & 92937 & 45137 \\
\hline $\mathrm{HSD}_{0.05}$ & 0.51 & 0.49 & - & - & - & - \\
\hline $\mathrm{CV}(\%)$ & 3.53 & 2.86 & - & - & - & - \\
\hline
\end{tabular}

$\circ$ Details of the fixed cost calculation have not been shown

['fb' = followed by, 'Pyrazo' = pyrazosulfuron-ethyl, 'buta' = butachlor, 'orthosul' = orthosulfamuron, 'aceto + bensul' $=$ acetochlor + bensulfuron methyl, 'buta + prop' $=$ butachlor + propanil and '2,4-D' $=2,4-\mathrm{D}$ amine]

Market price of commercial herbicides: pendimethalin $=\mathrm{Tk} .2525 \mathrm{ha}^{-1}$, pyrazosulfuronethyl = Tk. $390 \mathrm{ha}^{-1}$, butachlor $=$ Tk. $1550 \mathrm{ha}^{-1}$, pretilachlor $=\mathrm{Tk} .790 \mathrm{ha}^{-1}$, orthosulfamuron $=\mathrm{Tk} .1050 \mathrm{ha}^{-1}$, acetochlor+ bensulfuron methyl $=\mathrm{Tk} .756 \mathrm{ha}^{-1}$, butachlor+ propanil $=$ Tk. $910 \mathrm{ha}^{-1}$ and 2,4-D amine $=$ Tk. $1575 \mathrm{ha}^{-1}$. 
Manual weeding cost: 100 labours ha ${ }^{-1}$ for 4 weeding (season-long weed free) @ Tk. 250 labour $^{-1}$ day $^{-1}$, Herbicide application cost: 2 labours ha ${ }^{-1}$ round $^{-1} @$ Tk. 250 labour ${ }^{-1}$ day $^{-1}$, Market price of grain: Tk. 17,000 ton $^{-1}$, Market price of straw: Tk. 1500 ton $^{-1}$, Gross income $=\left\{\right.$ grain yield $\left(\mathrm{t} \mathrm{ha}^{-1}\right) \times$ market price $\left(\right.$ Tk. ton $\left.\left.{ }^{-1}\right)\right\}+$ $\left\{\right.$ straw yield $\left(\mathrm{t} \mathrm{ha}^{-1}\right) \times$ market price $\left(\right.$ Tk. ton $\left.\left.^{-1}\right)\right\}$, Net benefit $=$ Gross income Total cost.

\section{Conclusion}

Sole application of pre-emergence herbicide was not effective for controlling weeds in strip-tilled non-puddled transplanted rice. Sequential application of pyrazosulfuron-ethyl with orthosulfamuron followed by butachlor + propanil was the best under reduced tillage system that offered high grain yield with highest economic return. Pyrazosulfuron-ethyl followed by orthosulfamuron followed by 2,4-D amine, butachlor followed by orthosulfamuron and butachlor + propanil or 2,4-D amine were also performed better in respect of weed control and economic benefit. But, use of pyrazosulfuron-ethyl followed by butachlor + propanil/2,4-D amine or orthosulfamuron fb butachlor + propanil also could be effective and economically viable in strip tillage non-puddled transplanted rice.

\section{Acknowledgement}

This study was the part of the $\mathrm{PhD}$ research of the senior author who acknowledges ACIAR (Project LWR/2010/080 for funding the research project and providing a scholarship).

\section{References}

Ahmed, S. and Chauhan, B.S. 2014. Performance of different herbicides in dry-seeded rice in Bangladesh. Sci. World J. http://dx.doi.org/10.1155/2013/729418.

Awan, T.H., Cruz, P.C.S. and Chauhan, B.S. 2014. Ecological significance of rice (Oryza sativa) planting density and nitrogen rates in managing the growth and competitive ability of itchgrass (Rottboella cochinchinensis) in direct seeded rice systems. J. Pest. Sci. http://dx.doi.org/10.1007/s10340-014-0604-4.

Awan, T.H., Cruz, P.C.S. and Chauhan, B.S. 2015. Agronomic indices, growth, yieldcontributing traits, and yield of dry-seeded rice under varying herbicides. Field Crops Res. 177: 15-25.

Busi, R., Gaines, T.A., Vila-Aiub, M.M. and Powles, S.B. 2014. Inheritance of revolved resistance to a novel herbicide (pyroxasulfone). Plant sci. 217-218: 127-134.

Chauhan, B.S., 2012. Weed ecology and weed management strategies for dry-seeded rice in Asia. Weed Technol. 26: 1-13.

Chauhan, B.S., Awan, T.H., Abugho, S.B., Evengelista, G. and Yadav, S. 2015. Effect of crop establishment methods and weed control treatments on weed management, and rice yield. Field Crops Res. 172: 72-84.

Chauhan, B.S., Gill, G. and Preston, C. 2006. Influence of tillage systems on vertical distribution, seedling recruitment and persistence of rigid ryegrass (Lolium rigidum) seed bank. Weed Sci. 54: 669-676. 
Chhokar, R.S., Sharma, R.K., Gathala, M.K. and Pundir, A.K. 2014. Effects of crop establishment techniques on weeds and rice yield. Crop Prot. 64: 7-12.

Devasenpathy, P., Ramesh, T. and Gangwar, B. 2008. Efficiency indices for agriculture management research. Sumit Pal Jain for New India Publishing Agency, New Delhi, India.

Ekeleme, E., Kamara, A.Y., Oikeh, S.O., Chikoye, D. and Omoigui, L.O. 2007. Effect of weed competition on upland rice production in north-eastern Nigeria. African Crop Science Conference Proceedings. 8: 61-65.

Gill, J.S., Walia, S.S. and Gill, R.S. 2014. Direct seeded rice: an alternative rice establishment technique in north-west India: a review. Intl. J. Advance Res. 2(3): 375-386.

Halder, P., Maiti, S., Bhattacharya, S.P. and Banerjee, H. 2005. Comparative efficacy of pyrazosilfuron-ethyl (PSE) and its combination with molinate against weed complex of boro paddy. J. Crop and Weed 1(1): 49-53.

Haque, M.E., Bell, R.W., Islam, M.A. and Rahman, M.A. 2016. Minimum tillage unpuddled transplanting: An alternative crop establishment strategy for rice in conservation agriculture cropping systems. Field Crops Res. 185: 31-39.

Hartzler, R.G. and Owen, M.D. 1997. Weed management in conservation tillage systems. University Extension, Iowa State University. Available at: http://www.extension.iastate.edu/publications/PM1176.pdf

Hasanuzzaman, M., Islam, M.O. and Bapari, M.S. 2008. Efficacy of different herbicides over manual weeding in controlling weeds in transplanted rice. Aust. J. Crop Sci. 2(1): $18-24$.

Hossain, M.M., 2015. Recent perspective of herbicide: review of demand and adoption in world agriculture. J. Bangladesh Agric. Univ. 13(1): 19-30.

Islam, A.K.M.S., Hossain, M.M. and Saleque, M.A. 2014. Effect of unpuddled transplanting on the growth and yield of dry season rice (Oryza sativa L.) in high barind tract. The Agriculturists. 12(2): 91-97.

Katherisan, R.M., 2001. Sustainability of weed management practices in rice-black gram cropping system. In: First biennial conference in the new millennium on 'Ecofriendly weed management options for sustainable agriculture', University of Agricultural Science, Bangalore, p. 79.

Krishna, V., Mehrotra, M.B., Teufel, N. and Bishnoi, D.K. 2012. Characterizing the cereal systems and identifying the potential of conservation agriculture in South Asia. Socio-Economics Program Working Paper 5. Mexico, D.F. CIMMYT.

Kumar, S., Singh, S.S., Sundaram, P.K., Shivani and Bhatt, B.P. 2012. Agronomic management and production technique of unpuddled mechanical transplanted rice. Technical bulletin no. R-37/Pat-24.ICAR-RCER, Patna.

Kumar, V., Bellinder, R.R., Gupta, R.K. and Malik, R.K. 2008. Role of herbicide resistant rice in rice-wheat cropping system of India. Crop Prot. 27: 290-301.

Ladha, J.K., Kumar, V., Alam, M.M., Sharma, S., Gathala, M.K., Chandra, P., Saharawat, Y.S. and Balasubramania, V. 2009. Integrating crop and resource management technologies for enhanced productivity, profitability and sustainability of the ricewheat system in South Asia, In: Direct Seeding in Asian Rice Systems: Strategic 
Research Issues and Opportunities (Ladha, J.K., Singh, Y., Erenstein, O., Hardy, B. Eds.). International Rice Research Institute, Manila, Philippines. pp. 185-201.

Mahajan, G., Brar, L.S. and Walia, U.S. 2002. Phalaris minor response in wheat in relation to planting dates, tillage and herbicides. Indian J. Weed Sci. 34: 213-215.

Mahajan, G. and Chauhan, B.S. 2008. Performance of penoxsulam for weed control in transplanted rice. Pest Technol. 2(2): 114-116.

Mazid, M.A. 2001. Weed management implications of introducing dry-seeding of rice in the Barind Tract of Bangladesh. In: The BCPC international conference.

Mishra, J.S. and Singh, V.P. 2012. Tillage and weed control effects on productivity of a dry seeded rice-wheat system on a vertisol in Central India. Soil Till. Res. 123: 11-20.

Murphy, S.D., Clements, D.R., Belaoussoff, S., Kevan, P.G. and Swanton, C.J. 2006. Promotion of weed species diversity and reduction of weed seedbank with conservation tillage and crop rotation. Weed Sci. 54: 69-77.

Nalewaja, J.D. 2003. Weeds and Conservation Agriculture, in: Garcia-Torres, L., Martnez-Vilela, A., Holgado-Cabrera, A. and Gónzalez-Sánchez, E., (Eds.), Conservation Agriculture. Kluwer Academic Publishers. p. 201-210.

Olofintoye, J.A. and Mabbayad, B.B. 1980. Weed growth, establishment and yield of an upland rice variety under three tillage systems and four seeding rates. Phil. Agric. 63: $345-352$.

Owen, M.J. and Powles, S.B. 2009. Distribution and frequency of herbicide-resistant wild oat (Avena spp.) across the western Australian grain belt. Crop and Pasture Sci. 60: 25-31.

Pandey, S., Suphanchaimat, N. and Velasco, M.L. 2012. The patterns of spread and economics of a labour-saving innovation in rice production: the case of direct seeding in Northeast Thailand. Quarterly J. Intl. Agric. 51(4): 333-356.

Parvez, M.S., Salam, M.A., Kato-Noguchi, H. and Begum, M. 2013. Effect of cultivar and weeding regime on the performance of transplant aman rice. Intl J. Agric. Crop Sci. 6(11): 654-666.

Patra, A.K., Halder, J. and Tripathy, S.K. 2006. Chemical control in transplanted rice (Oryza sativa) in Hirakud Command area. Ann. Agric. Res. New Series 27(4): 385388.

Singh, S.S., Singh, A.K. and Sundaram, P.K. 2014. Agrotechnological options for upscaling agricultural productivity in eastern indo gangetic plains under impending climate change situations: A Review. J. Agrisearch 1(2): 55-65.

Swanton, C.J., Shrestha, A., Knezevic, S.Z., Roy, R.C. and Ball, B.R. 2000. Influence of tillage type on vertical weed seedbank distribution in a sandy soil. Canadian J. Plant Sci. 80: 455-457.

Timsina, J., Haque, Chauhan, B.S. and Johnson, D.E. 2010. Impact of tillage and rice establishment methods on rice and weed growth in the rice-maize-mungbean rotation in northern Bangladesh. In: 28th International Rice Research Conference, 8-12 November, 2010. Hanoi, Vietnam OP09: Pest, Disease and Weed management.

Zahan, T., Rahman, M.M., Hashem, A., Begum, M., Bell, R.W. and Haque, M.E. 2014. Weed control efficacy of herbicides in unpuddled transplanted aman (summer) rice. In: Regional Conference on Conservation Agriculture for Smallholders in Asia and Africa. 7-11 December, 2014, Mymensingh, Bangladesh. Pp. 110-111. 